\title{
Cancer of the lung in iron ore (haematite) miners
}

\author{
J. T. BOYD, ${ }^{1}$ R. DOLL, ${ }^{2}$ J. S. FAULDS, and J. LEIPER ${ }^{3}$ \\ M.R.C. Clinical Research Centre, University College Hospital Medical School, London
}

\begin{abstract}
Boyd, J. T., Doll, R., Faulds, J. S., and Leiper, J. (1970). Brit. J. industr. Med., 27, 97-105. Cancer of the lung in iron ore (haematite) miners. The mortality of Cumberland iron-ore miners has been studied by examining the death certificates of 5811 men resident in two local authority areas (Ennerdale R.D. and Whitehaven M.B.) who died between 1948 and 1967. Comparison of the iron miners' experience with (1) that of other local men and (2) the relevant national experience has provided an assessment of the suspected occupational risk of lung cancer associated with haematite mining. During the 20-year period there were 42 deaths attributed to lung cancer among iron mine employees resident in the study area: 36 of these occurred in miners working underground, which was significantly greater than that expected from local non-mining (20.6 deaths) or national (21.5 deaths) experience. In contrast to these findings, there was no evidence of any excess mortality from lung cancer among surface workers and, for iron miners as a whole, mortality from other cancers was close to the national experience. A parallel analysis of mortality among coal miners showed a deficit of deaths from lung cancer in line with other studies. The patterns of other respiratory mortality in the two local mining groups were also in line with previous experience, and confirmed the existence of a substantial silicotic hazard associated with haematite mining in Cumberland.

These findings strengthen previous necropsy evidence and indicate that West Cumberland iron-ore miners who work underground experience an occupational hazard of lung cancer. They suggest that the miners suffer a lung cancer mortality about $70 \%$ higher than 'normal'. The risk may be due to radioactivity in the air of the mines (average radon concentration of $100 \mathrm{p} \mathrm{Ci} /$ litre) or to a carcinogenic effect of iron oxide.
\end{abstract}

Established occupational risks of lung cancer include those run by miners working in a radioactive environment (Sikl, 1950; de Villiers and Windish, 1964; Wagoner, Archer, Lundin, Holaday, and Lloyd, 1965), by nickel workers (Doll, 1958; Morgan, 1958), by men engaged in the manufacture of chromates (Machle and Gregorius, 1948; Brinton, Frasier, and Koven, 1952; Bidstrup and Case, 1956), by those exposed to asbestos (Doll, 1955; Selikoff, Churg, and Hammond, 1964;

'M.R.C. Clinical Research Centre, University College Hospital Medical School, London, W.C.1

'Regius Professor of Medicine, Oxford University

'County Medical Officer, Cumberland
Wagner, Sleggs, and Marchand, 1960), by gas workers (Doll, Fisher, Gammon, Gunn, Hughes, Tyrer, and Wilson, 1965), and by men manufacturing mustard gas (Wada, Miyanishi, Nishimoto, Kambe, and Miller, 1968). Among other occupational groups, a relatively high lung cancer mortality has been reported for iron foundry workers (Turner and Grace, 1938), and postmortem findings among Cumberland iron-ore miners (Faulds and Stewart, 1956) have suggested that they, too, may be at similar risk.

The present paper reports a further study of Cumberland miners based on their mortality experience over the years 1948-67. The study was under- 
taken to complement and extend the earlier necropsy findings and in particular to ascertain whether death certificate data confirmed the suspected occupational risk of lung cancer. The answer was sought from a comparison of the causes of deaths in miners and in other men living in the same area, made possible by the extraction of death records of all men who had lived and died in the area during the period. By this means it was hoped to avoid any bias due to unrepresentative selection of cases, a bias difficult to eliminate from necropsy studies.

The investigation was also stimulated by knowledge of the results of a recent survey of radioactivity in mines carried out by the Radiological Protection Service. In three of the four iron mines in the Egremont area of West Cumberland, all measurements of the amount of radon in their air were at least 30 picocuries ( $p \mathrm{Ci}) /$ litre - the maximum permissible concentration recommended by the International Commission on Radiological Protection-and individual measurements ranged as high as $320 \mathrm{p} \mathrm{Ci}$ /litre (Duggan, Soilleux, Strong, and Howell, 1969). In view of the known association between radioactivity and lung cancer in other mining environments, these results strengthened the case for a closer examination of the mortality experienced by the local miners.

\section{The industry}

Haematite has been mined in West Cumberland since Roman times. The local deposits consist mainly of ferric oxide but also contain 10 to $12 \%$ silica and were too hard for drilling until the introduction of pneumatic drills in 1913. Before then, ore was mined by the relatively slow and less dusty "hammer and jumper' method. The improved efficiency of the early pneumatic drilling methods was accompanied by a great increase in the dust to which the miners were exposed, especially at the working face. Wet drills were introduced in 1925 , but they were at first unpopular and were often used dry when the manager was not present. As wet drilling came to be accepted and other modern methods of dust suppression were introduced, the working conditions improved and a standard of 2500 dust particles (under $5 \mu$ diameter with $10 \%$ silicas) per millilitre had been achieved by the middle fifties (Faulds, 1957). Under the old conditions with dry drills counts at the face were frequently many million (Craw, 1947a, b).

Until 1913 iron-ore mining was considered to be a healthy occupation (Royal Commission on Metalliferous Mines and Quarries, 1912). After the introduction of pneumatic drilling an increased frequency of bronchitis and emphysema among the miners was noted by several observers (Collis, 1919, 1923; Collis and Goadby, 1930). In one study 30 of 100 drillers and underground workers were found to have emphysema and the miners' main complaints were dyspnoea on exertion and chronic irritation of the nose and throat when working in a dusty atmosphere (Cronin, 1926). These first indications of respiratory hazard were quickly followed by the description of an underlying pulmonary lesion (Stewart and Faulds, 1934). Many cases of silicosis, and silico-tuberculosis, occurred subsequently, but later surveys provided encouraging signs of longterm benefit from the dust-suppressive measures that were introduced in the second half of the thirties (Craw, 1947a, b; Faulds, 1957).

\section{The data}

The vast majority of workers employed in the iron mines around Egremont live in the Ennerdale Rural District of Cumberland; a few normally reside in the adjoining Municipal Borough of Whitehaven (see Figure). This local concentration suggested that the records of deaths held by the Medical Officer of Health should provide data suitable for a study of their mortality. These records include copies of the death certificates of all persons dying in the two districts, together with those of persons who were resident in either district but died elsewhere. They could therefore provide information about causes of death of all men who died during employment in the iron mines and of a large proportion of the retired workers who had worked in the mines when they had last been employed. Control data were also available in national mortality rates and in the death records relating to other men who resided in the same area.

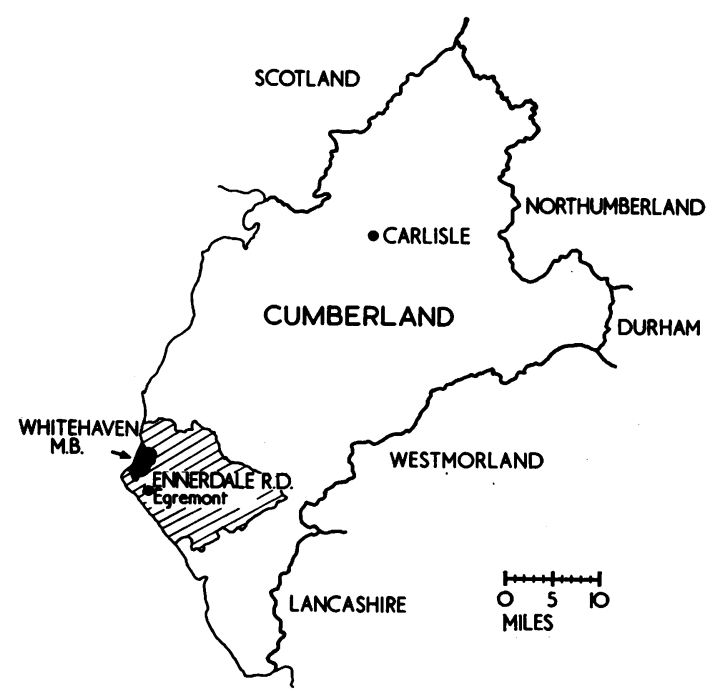

FIGURE Location of study area. 
Data for the 5811 men over 15 years of age who were resident in the defined area of West Cumberland and who died in the 20-year period 1948-67 are shown in Table 1 . The numbers of deaths are shown separately for the two administrative divisions, four causes, five occupations, and five age groups. The causes have been classified as cancer of the lung, all other cancer, respiratory causes or 'other causes', according to the diagnosis on the death certificate. Where two or more causes were given the death was classified to the underlying cause in accordance with international usage. Deaths were examined separately among iron miners who worked above or below ground, among coal miners at Whitehaven (again separately for those working above or below ground), and among the remaining non-miners ('all other occupations').

\section{Lung cancer among iron miners}

During 1948-67, 42 deaths among iron miners were attributed to cancer of the lung, 74 to other cancers, 174 to respiratory causes, and 396 to other causes. From these data it is impossible to calculate rates, because the numbers of men employed in the different occupations are not known. If, however, the experience of one of the groups is used as a standard, it is possible to estimate the numbers of deaths from each cause that would have been expected in the others. For this purpose, the most suitable group is that of 'all other occupations' (excluding iron-ore and coal miners). The total number of deaths in this group is large, the types of occupations numerous and varied, and it is unlikely that its total mortality has been unduly influenced by any single occupational factor. The expected number of deaths from, say, lung cancer among iron-ore miners can then be estimated by assuming that the ratio between the number due to lung cancer and the number due to 'other causes' (other than cancer or respiratory disease) should be the same at each age, as in the standard group. Deaths due to other cancers or to other respiratory disease are excluded from the calculation as these also may be associated with an occupational hazard. In using this ratio to estimate expected deaths among iron-ore miners, separate calculations were made for the two districts and for miners classified as working above or below ground. For example, there were 33 deaths due to lung cancer and 447 deaths due to 'other causes' among men aged 65-74 years resident in Ennerdale R.D. and employed in 'all other occupations'. There were 91 deaths due to 'other causes' among Ennerdale males of the same ayes employed underground in iron mining, and it is therefore estimated that the expected number of deaths from lung cancer among the underground miners is $\frac{33}{447} \times 91$, i.e.

TABLE 1

Number of Deaths from Specified Causes among Men Resident in Ennerdale R.D. and Whitehaven M.B. (1948-67) SUBDIVIDED BY AGE AND OCCUPATION

\begin{tabular}{|c|c|c|c|c|c|c|c|c|c|c|c|c|c|c|c|c|c|c|c|c|}
\hline \multirow{4}{*}{$\begin{array}{c}\text { Age at } \\
\text { death } \\
(y r s)\end{array}$} & \multicolumn{20}{|c|}{ Number of deaths among men employed in: } \\
\hline & \multicolumn{8}{|c|}{ Iron-mining } & \multicolumn{8}{|c|}{ Coal-mining } & \multirow{2}{*}{\multicolumn{4}{|c|}{ All other occupations }} \\
\hline & \multicolumn{4}{|c|}{ Underground } & \multicolumn{4}{|c|}{ Surface } & \multicolumn{4}{|c|}{ Underground } & \multicolumn{4}{|c|}{ Surface } & & & & \\
\hline & $\begin{array}{l}\text { Cancer } \\
\text { of lung }\end{array}$ & $\begin{array}{l}\text { Other } \\
\text { cancer }\end{array}$ & $\begin{array}{l}\text { Resp. } \\
\text { causes }\end{array}$ & $\begin{array}{l}\text { Other } \\
\text { causes }\end{array}$ & $\begin{array}{l}\text { Cance } \\
\text { of lung }\end{array}$ & $\begin{array}{l}\text { ther } \\
\text { ancer }\end{array}$ & $\begin{array}{l}\text { Resp. } \\
\text { causes }\end{array}$ & $\begin{array}{l}\text { ther } \\
\text { auses }\end{array}$ & $\begin{array}{l}\text { Cance } \\
\text { of lun }\end{array}$ & $\begin{array}{l}\text { Other } \\
\text { cancer }\end{array}$ & $\begin{array}{l}\text { Resp. } \\
\text { causes }\end{array}$ & $\begin{array}{l}\text { Other } \\
\text { causes }\end{array}$ & $\begin{array}{l}\text { Cance } \\
\text { of lung }\end{array}$ & $\begin{array}{l}\text { Dther } \\
\text { :ancer }\end{array}$ & $\begin{array}{l}\text { Resp. } \\
\text { causes }\end{array}$ & $\begin{array}{l}\text { Other } \\
\text { causes }\end{array}$ & $\begin{array}{l}\text { Cancer } \\
\text { of lung }\end{array}$ & $\begin{array}{l}\text { Other } \\
\text { cancer }\end{array}$ & $\begin{array}{l}\text { Resp. } \\
\text { causes }\end{array}$ & $\begin{array}{l}\text { Other } \\
\text { causes }\end{array}$ \\
\hline \multicolumn{21}{|c|}{ Ennerdale } \\
\hline $\begin{array}{l}\text { Under } 45 \\
45- \\
55- \\
65- \\
75+\end{array}$ & $\begin{array}{r}1 \\
5 \\
8 \\
14 \\
6\end{array}$ & $\begin{array}{r}1 \\
1 \\
12 \\
28 \\
23\end{array}$ & $\begin{array}{r}4 \\
11 \\
35 \\
55 \\
52\end{array}$ & $\begin{array}{r}13 \\
14 \\
43 \\
91 \\
133\end{array}$ & $\begin{array}{l}- \\
1 \\
3 \\
1 \\
1\end{array}$ & $\begin{array}{l}- \\
2 \\
4 \\
2\end{array}$ & $\begin{array}{l}1 \\
2 \\
3 \\
6 \\
2\end{array}$ & $\begin{array}{r}\overline{9} \\
18 \\
25 \\
28\end{array}$ & $\begin{array}{l}- \\
2 \\
3 \\
1 \\
-\end{array}$ & $\begin{array}{r}4 \\
2 \\
9 \\
16 \\
11\end{array}$ & $\begin{array}{r}1 \\
5 \\
7 \\
15 \\
18\end{array}$ & $\begin{array}{r}11 \\
9 \\
19 \\
73 \\
92\end{array}$ & $\frac{\bar{z}}{\overline{2}}$ & $\begin{array}{l}-\overline{1} \\
4 \\
4 \\
3\end{array}$ & $\begin{array}{l}\overline{2} \\
2 \\
1 \\
3\end{array}$ & $\begin{array}{r}5 \\
6 \\
4 \\
20 \\
28\end{array}$ & $\begin{array}{r}8 \\
23 \\
52 \\
33 \\
10\end{array}$ & $\begin{array}{l}18 \\
27 \\
67 \\
89 \\
84\end{array}$ & $\begin{array}{l}26 \\
37 \\
61 \\
68 \\
58\end{array}$ & $\begin{array}{l}100 \\
132 \\
305 \\
447 \\
556\end{array}$ \\
\hline $\begin{array}{l}\text { All ages } \\
(15+)\end{array}$ & 34 & 65 & 157 & 294 & 6 & 8 & 14 & 80 & 6 & 42 & 46 & 204 & 2 & 12 & 8 & 63 & 126 & 285 & 250 & 1,540 \\
\hline \multicolumn{21}{|c|}{ Whitehaven M.B. } \\
\hline $\begin{array}{l}\text { Under } 45 \\
45- \\
55- \\
65- \\
75+\end{array}$ & $\begin{array}{l}\bar{z} \\
\overline{2}\end{array}$ & $\begin{array}{l}\bar{z} \\
z\end{array}$ & $\begin{array}{l}- \\
1 \\
1 \\
-\end{array}$ & $\begin{array}{r}\frac{1}{2} \\
2 \\
2 \\
16\end{array}$ & $\begin{array}{l}\bar{z} \\
\overline{-}\end{array}$ & $\frac{-}{1}$ & $\begin{array}{l}\bar{z} \\
\overline{1}\end{array}$ & $\begin{array}{l}\overline{1} \\
\overline{-}\end{array}$ & $\begin{array}{l}- \\
8 \\
8 \\
9 \\
1\end{array}$ & $\begin{array}{r}5 \\
5 \\
23 \\
19 \\
23\end{array}$ & $\begin{array}{r}5 \\
6 \\
18 \\
25 \\
18\end{array}$ & $\begin{array}{r}29 \\
29 \\
54 \\
108 \\
222\end{array}$ & $\begin{array}{r}-3 \\
4 \\
2 \\
-\end{array}$ & $\begin{array}{r}2 \\
2 \\
4 \\
10 \\
3\end{array}$ & $\begin{array}{r}1 \\
4 \\
6 \\
3\end{array}$ & $\begin{array}{r}2 \\
9 \\
19 \\
38 \\
61\end{array}$ & $\begin{array}{r}6 \\
14 \\
29 \\
26 \\
6\end{array}$ & $\begin{array}{l}21 \\
23 \\
51 \\
79 \\
54\end{array}$ & $\begin{array}{l}26 \\
31 \\
45 \\
55 \\
53\end{array}$ & $\begin{array}{l}100 \\
102 \\
264 \\
370 \\
402\end{array}$ \\
\hline $\begin{array}{l}\text { All ages } \\
(15+)\end{array}$ & 2 & - & 2 & 21 & - & 1 & 1 & 1 & 22 & 75 & 72 & 442 & 9 & 21 & 14 & 129 & 81 & 228 & 210 & 1238 \\
\hline
\end{tabular}


6.72. The number actually observed was 14 . The results obtained by calculating expected numbers for each of the age groups studied and summing for all ages are shown in Table 2. Among all iron miners (underground and surface workers) the number of lung cancer deaths observed (42) was $50 \%$ higher than the number expected (28) ${ }^{1}$. In contrast, the number of deaths from other cancers (74) was very close to that expected (71). Separate examination of the underground and surface workers showed that the excess of lung cancer was confined to the former (observed 36, expected 20.58$)^{2}$ and was not present among the latter (observed 6, expected 7.13). Thus, iron miners working underground appeared to suffer a $75 \%$ increase in mortality from lung cancer. This result must be interpreted with caution because it is derived only from a comparison of proportions. A similar result would be obtained if lung cancer deaths among the standard population or deaths from other causes among the iron miners were abnormally low.

The first alternative can be tested by examining the iron miners' mortality in comparison with national rather than local standards. For this purpose, we used: (1) deaths in the combined rural districts of England and Wales (1948-67) for comparison with those in Ennerdale R.D., and (2) deaths in all municipal boroughs with populations under 50,000 in England and Wales (1948-67) for comparison with those in Whitehaven M.B. In both sets of data the numbers of deaths were divided as before and used in the same way to calculate expected deaths among iron miners in Ennerdale and Whitehaven respectively. The results, combining areas and summed for all ages, are shown in the bot-

$1 \mathrm{P}<0.05$
$\mathrm{P}<0.001$ tom row of Table 2. With respect to lung cancer mortality, the expected figures were closely similar to those calculated from the deaths among nonminers in the same way. The excess of lung cancer deaths among iron miners working underground persisted and the estimate of the excess risk was only slightly lower than that estimated from local mortality experience $(68 \%$ against $75 \%)$. It follows, therefore, that the excess cannot be attributed to an unusually low mortality from lung cancer in men in 'other occupations' in Cumberland. The results obtained with 'other cancers' (see below) also make it unlikely that the excess lung cancer mortality could be attributed to an unusually low mortality among iron miners from other causes.

Some of the excess may be due to a high standard of diagnosis associated with a high necropsy rate ( $56 \%$, see below), but this is unlikely to account for more than a small part of the excess as, even with a $100 \%$ necropsy rate, the prevalence of lung cancer is increased by only $13-17 \%$ (Heasman and Lipworth, 1966).

Pathology data The earlier study of lung cancer necropsies associated with iron mining (Faulds and Stewart, 1956) provided histological support for many of the death certificate diagnoses in the present survey. This post-mortem material was extended by a search of relevant records to bring together, as far as possible, all pathological data relating to lung cancer among iron miners in Ennerdale and Whitehaven during 1948-67. As compared with 42 iron miners certified as dying from lung cancer, the pathological data identified a total of 69 deaths from this cause among miners or ex-miners during the same period. Direct comparison of the two sets of data (Table 3) shows that post-mortem confirmation was available for 33

TABLE 2

COMPARISON OF ObSERVED AND EXPECTED MORTALITy AMONG Iron MiNe EMPLOYEes:

ENNERDALE R.D. AND WHITEHAVEN M.B. (1948-67)

(expected numbers, local non-mining experience in parentheses)

\begin{tabular}{|c|c|c|c|c|c|c|c|c|c|c|c|c|c|c|}
\hline \multirow{3}{*}{\multicolumn{2}{|c|}{$\begin{array}{c}\text { Age at } \\
\text { death } \\
\text { (yrs) }\end{array}$}} & & \multicolumn{12}{|c|}{ Number of deaths among iron mine employees } \\
\hline & & & \multicolumn{4}{|c|}{ Underground workers } & \multicolumn{4}{|c|}{ Surface workers } & \multicolumn{4}{|c|}{ All iron miners } \\
\hline & & & $\begin{array}{l}\text { Cancer } \\
\text { of lung }\end{array}$ & $\begin{array}{l}\text { Other } \\
\text { cancer }\end{array}$ & $\begin{array}{l}\text { Resp. } \\
\text { causes }\end{array}$ & $\begin{array}{l}\text { Other } \\
\text { causes }\end{array}$ & \multirow{2}{*}{$\begin{array}{l}\begin{array}{l}\text { Cancer } \\
\text { of lung }\end{array} \\
-(-\overrightarrow{7}) \\
1(1 \cdot 71) \\
3(3 \cdot 07) \\
1(1 \cdot 85) \\
1(0 \cdot 50)\end{array}$} & \multirow{2}{*}{$\begin{array}{c}\begin{array}{c}\text { Other } \\
\text { cancer }\end{array} \\
-(-) \\
-(2.07) \\
2(3.95) \\
5(4.98) \\
2(4 \cdot 23)\end{array}$} & $\begin{array}{l}\text { Resp. } \\
\text { causes }\end{array}$ & \multirow{2}{*}{$\begin{array}{c}\begin{array}{c}\text { Other } \\
\text { causes }\end{array} \\
- \\
10 \\
18 \\
25 \\
28\end{array}$} & $\begin{array}{l}\text { Cancer } \\
\text { of lung }\end{array}$ & $\begin{array}{l}\text { Other } \\
\text { cancer }\end{array}$ & $\begin{array}{l}\text { Resp. } \\
\text { causes }\end{array}$ & \multirow{2}{*}{$\begin{array}{c}\begin{array}{c}\text { Other } \\
\text { causes }\end{array} \\
14 \\
24 \\
63 \\
118 \\
177\end{array}$} \\
\hline $\begin{array}{l}\text { Under } 45 \\
45-\quad \ldots \\
55-\quad \ldots \\
65-\quad \ldots \\
75+\quad \ldots\end{array}$ & $\begin{array}{l}\cdots \\
\cdots \\
\cdots \\
\cdots\end{array}$ & $\begin{array}{l}\ldots \\
\cdots \\
\cdots \\
\cdots\end{array}$ & \begin{tabular}{|rl}
1 & $(1 \cdot 10)$ \\
5 & $(2 \cdot 44)$ \\
8 & $(7 \cdot 55)$ \\
14 & $(6 \cdot 86)$ \\
8 & $(2 \cdot 63)$
\end{tabular} & $\begin{array}{rr}1 & (2 \cdot 55) \\
1 & (2 \cdot 86) \\
12 & (9 \cdot 84) \\
28 & (18 \cdot 55) \\
23 & (22 \cdot 24)\end{array}$ & $\begin{array}{rr}4 & (3.64) \\
11 & (3.92) \\
36 & (8.94) \\
56(14.14) \\
52(15.98)\end{array}$ & $\begin{array}{r}14 \\
14 \\
45 \\
93 \\
149\end{array}$ & & & $\begin{array}{ll}1 & (-\overrightarrow{)}) \\
2 & (2 \cdot 82) \\
3 & (3 \cdot 60) \\
6 & (3 \cdot 80) \\
3 & (2 \cdot 92)\end{array}$ & & $\begin{array}{|rr|}1 & (1 \cdot 10) \\
6 & (4 \cdot 15) \\
11 & (10 \cdot 62) \\
15 & (8 \cdot 71) \\
9 & (3 \cdot 13)\end{array}$ & $\begin{array}{r}1(2.55) \\
1(4.93) \\
14(13.79) \\
33(23.53) \\
25(26.47)\end{array}$ & $\begin{array}{r}5(3.64) \\
13(6.74) \\
39(12.54) \\
62(17.94) \\
55(18.90)\end{array}$ & \\
\hline \multicolumn{2}{|c|}{ All ages $(15+)$} & $\cdots$ & $36(20 \cdot 58)$ & \multicolumn{2}{|c|}{$65(56.04) 159(46.62)$} & 315 & $6(7 \cdot 13)$ & $9(15 \cdot 23)$ & $15(13 \cdot 14)$ & 81 & $42(27 \cdot 71)$ & \multicolumn{2}{|c|}{$74(71 \cdot 27) 174(59 \cdot 76)$} & 396 \\
\hline All ages (1 & & . & $21 \cdot 48$ & 58.68 & $59 \cdot 88$ & & $\begin{array}{c}7 \cdot 34 \\
\text { (numbers }\end{array}$ & $\begin{array}{l}16.63 \\
\text { xpected fro }\end{array}$ & $\begin{array}{c}15 \cdot 90 \\
\text { om national }\end{array}$ & xperienc & $28 \cdot 82$ & $75 \cdot 31$ & $75 \cdot 78$ & \\
\hline
\end{tabular}


( $79 \%$ ) of the 42 cases recorded on death certificates. No record of any pathological findings was available for the other nine deaths certified as due to lung cancer, but hospital notes that were traced for five of them provided supporting evidence (bronchoscopy or $x$-ray). There remained 35 iron miners, or ex-miners, with lung cancer confirmed at necropsy whose death certificates recorded another occupation (22), a different cause of death (9), or both (4), and there was one lung cancer death where both cause and occupation were correctly stated on the certificate but the death, which had occurred in a hospital outside the present study area, had not been transferred to the deceased's normal area of residence. The combined data from both sources (i.e., death registrations and pathology records indicated that at least 78 iron miners, or ex-miners, developed lung cancer between 1948 and 1967.

Discrepancies of occupation between paired death certificates and post-mortem records are not surprising and it is probable that in most instances both records are correct, in that the death certificate is concerned with the deceased's most recent occupation whereas the pathological data record any history of iron mining whether current or past. It is, however, of interest to note that at least 22 , or $10 \%$, of the lung cancer deaths in men in 'other occupations' occurred in men known to have had previous experience of iron mining. ${ }^{3}$ By itself this gives some assurance that the excess of certified lung cancer deaths among iron miners is not merely a reflection of a tendency to link this occupation, on the death certificate, with any death from lung cancer. While differences as to cause between the two death records are at first sight more surprising, a possible explanation may lie in the issue of a death certificate by a coroner ( 12 of the 13 examples of this difference came to a coroner's post-mortem) on the basis of naked-eye findings without alteration to accord with any revision that may be suggested by later histology. A further factor may be that pneumoconiosis (mentioned on eight of the 13 death certificates) qualifies for compensation but lung cancer does not.

Post-mortem reports of lung cancer deaths were scrutinized for information allowing their classification by cell type. One hundred and fifty-seven reports (69 relating to iron-ore miners and 88 to men in other occupations) allowed such classification and suggested that oat-cell carcinoma was relatively more frequent among iron miners (27 out of 69 , or $37 \%$ ) than among other Cumberland

3Other evidence suggests that this is probably an underestimate. An enquiry by local health visitors as to the occupational history of the 126 men dying in Ennerdale R.D. from lung cancer and classified to 'other occupations' (Table 1) showed that as many as 54 of these men had at some stage worked at iron-ore mining.

\section{TABLE 3}

Comparison of Death Certificate and Postmortem Data Relating to lung Cancer Deaths AMONG IRON-MINERS: ENNERDALE R.D. AND WHITEHAVEN M.B. (1948-67)

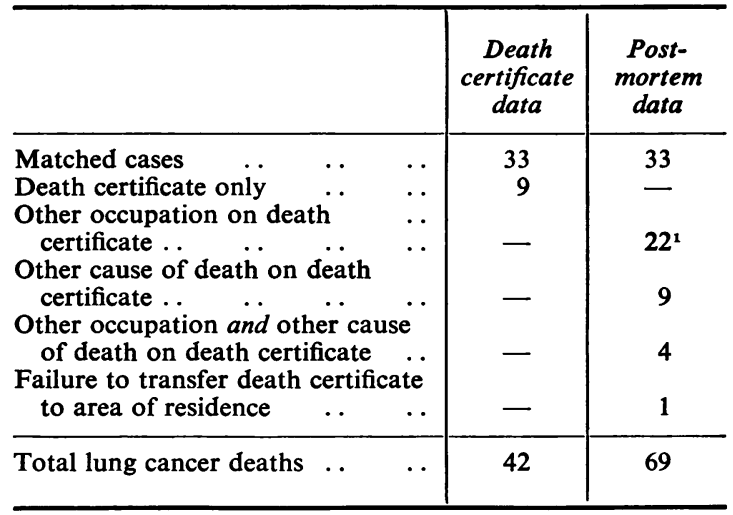

${ }^{1}$ Includes one case with histological confirmation but no post-mortem.

males dying from lung cancer ( 20 out of 88 , or $23 \%$ ). This high proportion of oat-cell tumours is close to that reported (Saccomanno, Archer, Saunders, James, and Beckler, 1964) among uranium miners $(43 \%)$. In addition to the 29 oat-cell tumours there were two other undifferentiated (spheroidal) cancers among Cumberland miners and this overall frequency of undifferentiated tumours ( 29 out of 69 , or $42 \%$ ) is again close to the proportion ( $44 \%$ ) of lung cancer deaths so classified in a necropsy study of French iron-ore miners (Roussel, Pernot, Schoumacher, Pernot, and Kessler, 1964).

\section{Lung cancer among coal miners}

The mortality data also allowed a similar analysis to be made for the other major mining group in West Cumberland. Observed deaths among coal miners, divided, as before, into five age groups, four causes and two employment categories, were again compared with the numbers expected from local non-mining experience (Table 4$)^{4}$. In contrast to the previous analysis, this comparison did not provide evidence of any occupational risk of lung cancer. Among underground coal miners, deaths due to lung cancer (28) were some $20 \%$ below the number expected (35) from local mortality experience, a deficiency which is consistent with the findings in several other studies (James, 1955; Doll, 1958; Goldman, 1965). Again, however, there was close agreement between the observed and expected numbers of lung cancer deaths among surface workers.

'Calculated by the same methods as used in assessing the mortality experience of iron miners. 
TABLE 4

Comparison of Observed and Expected Mortality among Coal Mine Employees:

ENNERDALE R.D. AND WHITEHAVEN M.B. (1948-67)

(expected numbers, local non-mining experience in parentheses)

\begin{tabular}{|c|c|c|c|c|c|c|c|c|c|c|c|c|c|c|c|}
\hline \multirow{3}{*}{$\begin{array}{l}\text { Age at } \\
\text { death } \\
(y r s)\end{array}$} & \multicolumn{15}{|c|}{ Number of deaths among coal mine employees } \\
\hline & \multicolumn{6}{|c|}{ Underground workers } & \multicolumn{4}{|c|}{ Surface workers } & \multicolumn{5}{|c|}{ All coal miners } \\
\hline & $\begin{array}{l}\text { Cancer } \\
\text { of lung }\end{array}$ & & $\begin{array}{l}\text { Dther } \\
\text { ancer }\end{array}$ & & $\begin{array}{l}\text { Resp. } \\
\text { auses }\end{array}$ & $\begin{array}{l}\text { Other } \\
\text { causes }\end{array}$ & $\begin{array}{l}\text { Cancer } \\
\text { of lung }\end{array}$ & $\begin{array}{l}\text { Other } \\
\text { cancer }\end{array}$ & $\begin{array}{l}\text { Resp. } \\
\text { causes }\end{array}$ & $\begin{array}{c}\text { Other } \\
\text { causes }\end{array}$ & $\begin{array}{l}\text { Cancer } \\
\text { of lung }\end{array}$ & & $\begin{array}{l}\text { Dther } \\
\text { ancer }\end{array}$ & $\begin{array}{l}\text { Resp. } \\
\text { causes }\end{array}$ & $\begin{array}{l}\text { Other } \\
\text { causes }\end{array}$ \\
\hline $\begin{array}{l}\text { Under } 45 \\
45- \\
55- \\
65- \\
75+\end{array}$ & $\begin{array}{rr} & (2.62) \\
6 & (5.55) \\
11 & (9.17) \\
10 & (12.98) \\
1 & (4.96)\end{array}$ & $\begin{array}{r}9 \\
7 \\
32 \\
35 \\
34\end{array}$ & $\begin{array}{r}(8 \cdot 07) \\
(8 \cdot 38) \\
(14 \cdot 60) \\
(37 \cdot 59) \\
(43 \cdot 72)\end{array}$ & $\begin{array}{r}6 \\
11 \\
25 \\
40 \\
36\end{array}$ & $\begin{array}{l}(10.40) \\
(11 \cdot 33) \\
(13.00) \\
(27 \cdot 16) \\
(38.87)\end{array}$ & $\begin{array}{r}40 \\
38 \\
73 \\
181 \\
314\end{array}$ & $\begin{array}{rr}- & (0.52) \\
3 & (2 \cdot 29) \\
4 & (2 \cdot 77) \\
4 & (4 \cdot 15) \\
- & (1.41)\end{array}$ & $\begin{array}{r}2(1.32) \\
3(3.26) \\
8(4.55) \\
14(12 \cdot 09) \\
6(12 \cdot 42)\end{array}$ & $\begin{array}{ll}1 & (1.82) \\
2 & (4.42) \\
6 & (4.04) \\
7 & (8.69) \\
6 & (10.96)\end{array}$ & $\begin{array}{r}7 \\
15 \\
23 \\
58 \\
89\end{array}$ & $\begin{array}{r}-(3 \cdot 14) \\
9(11 \cdot 84) \\
15(11.94) \\
14(17 \cdot 13) \\
1(6.37)\end{array}$ & $\begin{array}{l}11 \\
10 \\
40 \\
49 \\
40\end{array}$ & $\begin{array}{l}(9.39) \\
(11.64) \\
(19.15) \\
(49.68) \\
(56.14)\end{array}$ & $\begin{aligned} 7 & (12 \cdot 22) \\
13 & (15 \cdot 75) \\
31 & (17 \cdot 04) \\
47 & (35 \cdot 85) \\
42 & (49 \cdot 83)\end{aligned}$ & $\begin{array}{r}47 \\
53 \\
96 \\
239 \\
403\end{array}$ \\
\hline $\begin{array}{c}\text { All ages } \\
(15+)\end{array}$ & $28(35 \cdot 28)$ & 117 & $(112 \cdot 36)$ & 118( & $(100 \cdot 76)$ & 646 & $11(11 \cdot 14)$ & $33(33 \cdot 64)$ & $22(29.93)$ & 192 & $39(46 \cdot 42)$ & 150 & $(146 \cdot 00)$ & $140(130 \cdot 69)$ & 838 \\
\hline $\begin{array}{c}\text { All ages } \\
15+\end{array}$ & $43.98^{1}$ & & $117 \cdot 97$ & & $127 \cdot 75$ & & $\begin{array}{c}12 \cdot 73^{1} \\
\text { (numbers ex }\end{array}$ & $\begin{array}{r}33.87 \\
\text { cted from }\end{array}$ & $\begin{array}{c}36.89 \\
\text { ional exper }\end{array}$ & nce) & $56 \cdot 71^{1}$ & & $151 \cdot 84$ & $164 \cdot 64$ & \\
\hline
\end{tabular}

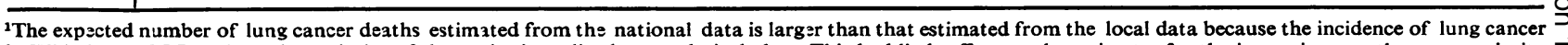

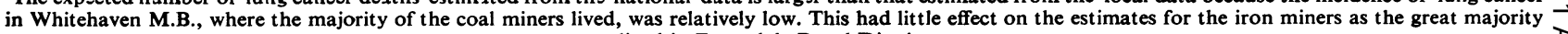
lived in Ennerdale Rural District.

Deaths due to respiratory causes

A risk of silicosis from iron mining in West Cumberland has been well documented (Stewart and Faulds, 1934; Faulds, 1957), but there has been no report of any comparable hazard from coal mining in the same area. The patterns of respiratory mortality that emerged from our study are entirely consistent with this difference between the two occupations. Thus among underground iron miners (Table 2) there was a marked excess of deaths certified as due to respiratory disease other than cancer $(166 \%)$; while among underground coal miners (Table 4) the excess $(17 \%)$ was much smaller.

A sub-division of respiratory deaths by cause for each of the mining groups and for all other occupations (Table 5) provided further information about the differing patterns of respiratory disease. Thus, among 174 haematite miners there were 98
$(56 \%)$ whose death had been certified to pneumoconiosis; among coal miners the comparable proportion was 13 out of $140(9 \%)$. Calculation of the expected distribution of these respiratory deaths standardized for age and based on the experience of the non-mining population-gave some further measure of the pneumoconiosis hazard of iron mining and indicated that it was indeed largely responsible for the excess respiratory mortality (other than that due to cancer) among haematite miners. It also appeared that with the possible exception of pulmonary tuberculosis, the pattern of respiratory mortality among coal miners was similar to that of local non-miners. One interesting feature of respiratory mortality among all other occupations was the inclusion of 30 deaths certified as due to pneumoconiosis among the 460 total respiratory deaths. Most, if not all, of these 30 men

TABLE 5

Distribution of Respiratory Deaths among Miners and All Other Ocupations by Cause

\begin{tabular}{|c|c|c|c|c|c|c|c|}
\hline \multirow{2}{*}{\multicolumn{3}{|c|}{ Cause of death (I.C.D. no. in parentheses) }} & \multicolumn{5}{|c|}{ Number of deaths } \\
\hline & & & \multicolumn{2}{|c|}{ Iron miners ${ }^{1}$} & \multicolumn{2}{|c|}{ Coal miners 1} & \multirow{2}{*}{$\begin{array}{c}\text { All other occupations } \\
24 \\
6 \\
65 \\
103 \\
208 \\
54\end{array}$} \\
\hline $\begin{array}{l}\text { Pneumoconiosis (523-4) } \\
\text { Pneumoconiosis + respiratory ty } \\
\text { Other respiratory tuberculosis ( } 0 \\
\text { Influenza and pneumonia (480-3, } \\
\text { Chronic bronchitis and emphyse } \\
\text { Other respiratory causes }\end{array}$ & $\begin{array}{l}\ldots \\
\text { rculosis }(001) \\
\text { 8) } \quad \ldots \\
0-3) \quad \ldots \\
(502,527 \cdot 1) \\
\ldots \quad \ldots\end{array}$ & $\begin{array}{l}\cdots \\
\cdots \\
\cdots \\
\cdots \\
\cdots \\
\cdots\end{array}$ & $\begin{array}{r}61 \\
37 \\
12 \\
20 \\
37 \\
7\end{array}$ & $\begin{array}{r}(10 \cdot 4) \\
(1 \cdot 8) \\
(13 \cdot 8) \\
(41 \cdot 8) \\
(85 \cdot 9) \\
(20 \cdot 2)\end{array}$ & $\begin{array}{r}8 \\
5 \\
18 \\
34 \\
59 \\
16\end{array}$ & $\begin{array}{r}(8 \cdot 1) \\
(1 \cdot 6) \\
(13 \cdot 2) \\
(33 \cdot 0) \\
(67 \cdot 8) \\
(16 \cdot 3)\end{array}$ & \\
\hline All respiratory causes $(470-527)$ & .. & .. & 174 & $(173 \cdot 9)$ & 140 & $(140 \cdot 0)$ & 460 \\
\hline
\end{tabular}

'Figures in parentheses show 'expected' distribution, standardized for age, based on non-mining experience. 
are likely to have had previous mining experience, so that data confined to men described as miners on death certificates underestimate the toll of this occupational disease, and may similarly underestimate the rate of occupational lung cancer.

\section{Deaths from other cancers}

The observed number of deaths from cancers other than lung cancer were, in each group of miners, similar to the numbers expected from the experience of men in other occupations (iron miners-74 against 71.3 expected; coal miners -150 against 146.0 expected). The expected numbers were, moreover, similar irrespective of whether they were calculated from other local or national experience (iron miners $71 \cdot 3$ and $75 \cdot 3$ respectively).

\section{Discussion}

A causative link between iron-ore mining and lung cancer was first suggested in an earlier necropsy study (Faulds and Stewart, 1956). This study found that: (1) the prevalence of lung cancer at necropsy among iron miners over 30 years increased sharply from $4.4 \%$ in 1932-47 (four in 91 necropsies) to $14.6 \%$ in 1948-53 (13 in 89 necropsies); (2) the prevalence was greater in necropsies on iron miners than on other Cumberland males of approximately the same age distribution, i.e., $9.4 \%$ (17 in 180 necropsies) against $2.0 \%$ (45 in 2221 necropsies) ${ }^{5}$ and (3) at least six growths appear to have arisen from sidero-silicotic nodules. This evidence raised a strong suspicion of an occupational risk but it was not conclusive. The prevalence of lung cancer had increased sharply throughout England during the same period and it was impossible to be sure that the incidence among the miners as a whole was really higher than normal. Post-mortem data of this type are difficult to interpret, because subjects who come to necropsy may not be representative of the population from which they are drawn. Even in the period between 1948 and 1953 only $56 \%$ of the miners who died came to necropsy. Compensation is payable if death is attributed to silicosis and those who came to necropsy are likely to have included the great majority of miners dying with pulmonary symptoms. It remained possible, therefore, that the true incidence may have been as low as 13 cases among 160 miners $(8.1 \%)$, a figure not very different from that which would be expected from national rates. Among other Cumberland males, on the other hand, the reasons for which necropsy was performed were presumably different. The most important is likely to have been sudden death, so

'The comparable proportions among Cumberland men coming to necropsy between 1954 and 1967 were $18.5 \%$ for iron miners (68 out of 367 ) and $3.3 \%$ for other men (193 out of 5796 ). that the proportion of necropsy cases showing evidence of lung cancer may have been below the average for the population as a whole.

Our analysis allows some further assessment of these findings. It does not, of course, provide the direct measurement of risk that would be provided by a cohort study of the experience of an iron mining population defined from nominal rolls of current and past employees. No long-term employment records, however, were available and in their absence the study was based on a proportional analysis of local death certificate data. The latter comprised records of all male deaths occurring between 1948 and 1967 in Whitehaven M.B. and Ennerdale R.D., and were therefore unaffected by the selective biases that are inherent in necropsy data. Again, separate analysis of both the iron miners' and coal miners' experience ensured that, in the local Cumberland situation, the remaining mortality data relating to all other occupations were unaffected by major occupational hazards and provided a reasonable baseline for the proportional approach that was used. The validity of the approach was also supported by the internal consistency of the results, notably the finding that: (1) the excess of lung cancer deaths among iron-ore miners was confined to underground workers; (2) separate estimates of the lung cancer risk derived from local and national records agreed closely; (3) there was no material difference between the observed and expected mortality due to 'other cancer', and (4) the estimated deficiency of lung cancer deaths among underground coal miners and the pattern of respiratory mortality in both mining groups were in line with previous experience.

All these findings suggest that the excess mortality from lung cancer observed among iron-ore miners in West Cumberland indicates a real occupational hazard. They confirm the previous necropsy evidence and provide some measure of the risk involved. Compared with the total of 36 deaths of underground miners certified as due to lung cancer the numbers expected from other local and national records were 20.6 and 21.5 respectively. Both comparisons suggest that, as measured by death registration data, the miners suffer a lung cancer mortality some $70 \%$ higher than 'normal'. The ascertainment, from necropsy data, that 22 out of 207 lung cancer deaths assigned to other occupations related to men with previous experience of iron mining provided some assurance that this estimate is not unduly inflated by the preferential linking of lung cancer deaths with the occupation of iron-ore mining. Indeed the risk may be underestimated, but even so the excess risk cannot be much greater than $100 \%$ - an order of risk that is relatively low compared with some other occupational hazards of lung cancer. 
One possible explanation of the difference between the experience of haematite and coal miners in the same area is that the former are permitted to smoke when underground at work, whilst the latter are not. If the role of cigarette smoking is to be excluded with certainty, it will be necessary to have definite data on the miners' smoking habits. Such data are not available, but it may be noted that one of us (J.S.F.) found little difference between the smoking habits of iron and coal miners in Cumberland in a small sample survey and that coal miners who smoke cigarettes have been found to compensate for the ban on smoking underground by smoking more at other times (Higgins, Oldham, Cochrane, and Gilson, 1956; and see Goldman, 1965).

Unless complicated by silicosis, the siderosis caused by pulmonary retention of $\mathrm{Fe}_{2} \mathrm{O}_{3}$ or $\mathrm{Fe}_{3} \mathrm{O}_{4} \mathrm{H}_{2} \mathrm{O}$ has long been considered innocuous. The present findings, however, and indications of a similar lung cancer risk among iron-ore miners in France (Monlibert and Roubille, 1960; Roussel et al., 1964) again raise the question of whether iron itself might be a causative factor. In addition to the evidence from mining experience a raised lung cancer mortality has been reported among foundry workers, smiths, and metal grinders (Turner and Grace, 1938; McLaughlin and Harding,1956). In a study of deaths certified as due to lung cancer in the whole of England and Wales between 1921 and 1938, Kennaway and Kennaway (1947) found 39 deaths among metal grinders compared with a calculated expected number of 22.2. The ratio of the observed and expected deaths (1.76 to 1 , a ratio close to that found in the present study of iron miners) was exceeded only by three groups of gas or pitch workers out of the 56 occupational groups examined. Successive studies of occupational mortality in England and Wales (Registrar-General, 1938, 1958) have also shown a slightly increased lung cancer mortality for iron and steel workers and a similar excess has been demonstrated in Scotland (Registrar-General for Scotland, 1956; Morrison, 1957).

In the laboratory field, iron has received less attention than many other metals though an early study demonstrated the influence of iron oxide, in conjunction with precipitated silica, on the incidence of primary lung tumours in mice (Campbell, 1940) and more recently Saffiotti, Cefis, Kolb, and Shubik (1965) showed that haematite dust activated the carcinogenic effect of tar droplets installed intra-tracheally into Syrian hamsters. Other investigations have high-lighted the carcinogenic potency of at least one iron compound - a complex of ferric hydroxide and dextran (Richmond, 1957, 1959). Haddow and Horning (1960) confirmed the high yield of tumours following subcutaneous injection of this complex in mice and rats (in one experiment 18 of 23 mice surviving six months developed sarcomas at the site of injection) but left open the question of whether the effect was specifically dependent on iron. In view of the suspected occupational risk of iron-ore miners, however, they speculated whether iron oxide itself might possess greater relevance than had hitherto been thought, as a common carcinogenic factor in the chromate, haematite, nickel, and asbestos industries.

Another possibility, however, must also be considered. The recent survey carried out by the Radiological Protection Service (Duggan et al., 1969) found high concentrations of radon in the air in three of four mines in the Egremont area, with 22 measurements ranging from $30 \mathrm{p} \mathrm{Ci} /$ litre to above $300 \mathrm{p} \mathrm{Ci} /$ litre, i.e., none was below the maximum permissible level recommended by the International Commission on Radiological Protection $(30 \mu \mathrm{Ci}$ / litre). This evidence of an increased level of radiation suggests a parallel with other mining situations where radioactivity is generally held responsible for an occupational lung cancer hazard. The link with radioactivity was first recognized among the miners of Schneeberg and Jacymov, where the mines have been worked successively for silver, nickel, cobalt, bismuth, arsenic, radium, and uranium. At one time it was estimated that $90 \%$ of tumours causing death among Schneeberg miners were bronchial in origin and that somewhere between 40 and $75 \%$ of all those regularly employed in the mines died from lung cancer (see Doll, 1959). More recent reports have demonstrated similar hazards among fluorspar miners in Newfoundland (de Villiers and Windish, 1964) and uranium miners in Colorado (Wagoner, Archer, Carroll, Holaday, and Lawrence, 1964), and among the latter Wagoner et al. (1965) have recorded a quantitative relationship between radiation exposure and the risk of developing the disease.

The data for the Cumberland miners are restricted to their mortality experience between 1948 and 1967 and a 1968 sample of the radon levels in the local mines, and they do not permit any detailed examination of risk in terms of radiation exposure. It seems clear that the lung cancer risk to Cumberland haematite miners is much less than that estimated for the Schneeberg and Jacymov, Newfoundland or Colorado mining groups, but it is also apparent from a recent review of estimated radon concentrations in the latter mines (de Villiers and Windish, 1964) that exposure to radon is of a lower order in Cumberland. Thus in Cumberland, an average radon concentration of $100 \mathrm{p} \mathrm{Ci} /$ litre compares with an estimated $2900 \mathrm{p} \mathrm{Ci} /$ litre measured after considerable improvement had been affected in Schneeberg, and the highest Cumberland measurement $(320 \mathrm{p} \mathrm{Ci} /$ litre) is also far below the comparable figures of $25000 \mathrm{p} \mathrm{Ci} /$ litre and $59000 \mathrm{p} \mathrm{Ci} /$ litre in the New- 
foundland and Colorado mines respectively. It may be, therefore, the upper limit of a two-fold increase in lung cancer estimated for the West Cumberland iron miners is compatible with their lesser exposure to radon in comparison with that of the three other mining groups for whom risk estimates extend upwards from 10 times normal for the Colorado miners (Wagoner et al., 1964). If radon is responsible for the lung cancer hazard associated with haematite mining, the question arises of its origin. Representative samples of exposed rock do not reveal any unusual radioactivity (Soilleux, 1968) and it may be that the radon is carried in by mine water, as is believed in the Newfoundland fluorspar mines (de Villiers and Windish, 1964).

If the carcinogenic factor is iron oxide the risk may be expected to disappear with the disappearance of silicosis. If it is radon, the risk may be more likely to persist.

We are grateful to Dr. S. Smith, former Area Medical Officer, Southern Area Cumberland, for his help in providing the death certificate records, and to Mrs E. Goldenberg and Mrs. P. M. Morris who assisted in their analysis.

\section{References}

Bidstrup, P. L., and Case, R. A. M. (1956). Carcinoma of the lung in workmen in the bichromates-producing industry in Great Britain. Brit. J. industr. Med., 13, 260-264.

Brinton, H. P., Frasier, E. S., and Koven, A. L. (1952). Morbidity and mortality experience among chromate workers. Publ. Hlth Rep. (Wash.), 67, 835-847.

Campbell, J. A. (1940). Effects of precipitated silica and of iron oxide on the incidence of primary lung tumours in mice. Brit. med. J., 2, 275-280.

Collis, E. L. (1919). Milroy Lectures (1915): Industrial Pneumoconioses, with special reference to Dust-Phthisis. [Reprinted from Public Health] H.M.S.O., London.

(1923). An inquiry into the mortality of coal- and metalliferous miners in England and Wales. Proc. roy. Soc. Med. Sect. of Epid. and State Med., 16, 85-101.

and Goadby, K. W. (1930). Dust inhalation and iron ore mining. J. industr. Hyg., 12, 266-280.

Craw, J. (1947a). The control and elimination of silicosis in the west coast haematite iron ore industry. Brit. J. industr. Med., 4, 30-47.

(1947b). Silicosis, Pneumokoniosis and Dust Suppression in Mines; (Craw, b). The control of silicosis in the haematite mines in the North West of England, pp. 68-87; Plates I-XIV at the end of vol. Proceedings at Conferences, held in London, 1947, Institution of Mining Engineers and Institution of Mining and Metallurgy, London.

Cronin, A. J. (1926). Dust inhalation by haematite miners. J. industr. Hyg., 8, 291-295.

Doll, R. (1955). Mortality from lung cancer in asbestos workers. Brit. J. industr. Med., 12, 81-86.

(1958). Cancer of the lung and nose in nickel workers. Ibid., 15, 217-223.

(1959). Occupational lung cancer: a review. Ibid., 16, 181-190.

—, Fisher, R. E. W., Gammon, E. J., Gunn, W., Hughes, G. O. Tyrer, F. H., and Wilson, W. (1965). Mortality of gasworkers with special reference to cancers of the lung and bladder, chronic bronchitis, and pneumoconiosis. Ibid., 22, 1-12.

Duggan, M. J., Soilleux, P. J., Strong, J. C., and Howell, D. M. (1969). The exposure of U.K. miners to radon. In press.

Faulds, J. S. (1957). Haematite pneumoconiosis in Cumberland miners. J. clin. Path., 10, 187-199. [Aug.].

, and Stewart, M. J. (1956). Carcinoma of the lung in haematite miners. J. Path. Bact., 72, 353-366.
Goldman, K. P. (1965). Mortality of coal-miners from carcinoma of the lung. Brit. J. industr. Med., 22, $72-77$.

Haddow, A., and Horning, E. S. (1960). On the carcinogenicity of an iron-dextran complex. J. nat. Cancer Inst., 24, 109-147.

Heasman, M. A., and Lipworth, L. (1966). Accuracy of Certification of Cause of Death, General Registrar's Office. Studies on Medical and Population Subjects. No. 20, H.M.S.O. London.

Higgins, I. T. T., Oldham, P. D., Cochrane, A. L., and Gilson, J. C. (1956). Respiratory symptoms and pulmonary disability in an industrial town; survey of a random sample of the population. Brit. med. J., 2, 904-910.

James, W. R. L. (1955). Primary lung cancer in South Wales coalworkers with pneumoconiosis. Brit. J. industr. Med., 12, 87-91.

Kennaway, E. L., and Kennaway, N. M. (1947). A further study of the incidence of cancer of the lung and larynx. Brit. J. Cancer, 1 , 260-298.

McLaughlin, A. I. G., and Harding, H. E. (1956). Pneumoconiosis and other causes of death of iron and steel foundry workers. Arch, industr. Hlth, 14, 350-378.

Machle, W., and Gregorius, F. (1948). Cancer of respiratory system in United States chromate-producing industry. Publ. Hlth Rep. (Wash.), 63, 1114-1127.

Monlibert, L., and Roubille, R. (1960). A propos du cancer bronchique chez le mineur de fer. J. franc. Méd. Chir. thor., 14, 435-439.

Morgan, J. G. (1958). Some observations on the incidence of respiratory cancer in nickel workers. Brit. J. industr. Med., 15, 224-234.

Morrison, S. L. (1957). Occupational mortality in Scotland. Ibid., 14, 130-132.

Registrar-General. (1938). Decennial Supplement, England and Wales, 1931, Part IIA. Occupational Mortality. H.M.S.O., London.

(1958). Decennial Supplement, England and Wales, 1951. Occupational Mortality, Part II. H.M.S.O., London.

Registrar-General for Scotland. (1956). Annual report, 1955, No. 101, Appendix IX, 75. H.M.S.O., Edinburgh.

Richmond, H. G. (1957). Induction of sarcoma in rats by an irondextran complex. Scot. med. J., 2, 169.

(1959). Induction of sarcoma in the rat by iron-dextran complex. Brit. med. J., 1, 947-949.

Roussel, J., Pernot, C., Schoumacher, P., Pernot, M., and Kessler, Y. (1964). Considérations statistiques sur le cancer bronchique du mineur de feu du bassin de Lorraine. J. Radiol. Electrol., 45, 541-546.

Royal Commission on Metalliferous Mines and Quarries (1912). Minutes of Evidence, Vol. 1, p. 7, Question 153. 10th June, 1910. [Cd. 6390.] H.M.S.O., London.

Saccomanno, G., Archer, V. E., Saunders, R. P., James, L. A., and Beckler, P. A. (1964). Lung cancer of uranium miners on the Colorado plateau. Hlth Phys., 10, 1195-1201.

Saffiotti, U., Cefis, F., Kolb, L. H., and Shubik, P. (1965). Experimental studies of the conditions of exposure to carcinogens for lung cancer induction. J. Air Pollut. Control Ass., 15, 23-25.

Selikoff, I. J., Churg, J., and Hammond, E. C. (1964). Asbestos exposure and neoplasia. J. Amer. med. Ass., 188, 22-26.

Sikl, H. (1950). The present status of knowledge about the Jachymov disease (Cancer of the lungs in the miners of the radium mines). Acta Un. int. Cancr., 6, 1366-1375.

Soilleux, P. J. (1968). Personal communication.

Stewart, M. J., and Faulds, J. S. (1934). The Pulmonary fibrosis of haematite miners. J. Path. Bact., 39, 233-253.

Turner, H. M., and Grace, H. G. (1938). An investigation into cancer mortality among males in certain Sheffield trades. J. Hyg (Lond.), 38, 90-103.

de Villiers, A. J., and Windish, J. P. (1964). Lung cancer in a fluorspar mining community. I. Radiation, dust and mortality experience. Brit. J. industr. Med., 21, 94-109.

Wada, S., Miyanishi, M., Nichimoto, K., Kambe, S., and Miller, R. W. (1968). Mustardl gas as a cause of respiratory neoplasia in man. Lancet, 1, 1161-1163.

Wagner, J. C., Sleggs, C. A., and Marchand, P. (1960). Diffuse pleural mesothelioma and asbestos exposure in the North Western Cape Province. Brit. J. industr. Med., 17, 260-271.

Wagoner, J. K., Archer, V. E., Carroll, B. E., Holaday, D. A., and Lawrence, P. A. (1964). Cancer mortality patterns among U.S. uranium miners and millers, 1950 through 1962. J. nat. Cancer Inst., 32, 787-801.

, Lundin, F. E., Holaday, D. A., and Lloyd, J. W. (1965). Radiation as the cause of lung cancer among uranium miners. New Engl. J. Med., 273, 181-188.

Received for publication, September 8, 1969. 